\title{
Pengembangan Modul Elektronik Berbasis POEI \\ (Prediksi, Observasi, Ekperimen, Interpretasi) pada Mata Kuliah Fisika Teknik
}

\author{
Development of Electronic Module Based POEI \\ (Prediction, Observation, Experiments, Interpretation)in the Technical Physics
}

\author{
Dewi Puspita Sari, Imam Syofii \& Rukiyah \\ FKIP, Universitas Sriwijaya, Palembang, Sumatera Selatan, Indonesia \\ d.puspita18@gmail.com
}

\begin{abstract}
Abstrak
Penelitian ini bertujuan untuk: (1) Menghasilkan Media Pembelajaran Dalam Bentuk E-Modul Berbasis POEI (Prediksi, Observasi, Ekperimen, Interpretasi) Pada Mata Kuliah Fisika Teknik yang valid, praktis dan efektif. Prosedur pengembangan terdiri dari empat tahap yaitu: Define (Pendefinisian), Design (Perencanaan), Develop (Pengembangan) dan Desseminate (Penyebarluasan). Kevalidan modul elektronik fisika teknikdilihat dari hasil validasi materi dan media. Skor aktual yang didapatkan dari validasi materi adalah $80 \%$ dan ini masuk kategori valid. Kemudian untuk validasi media skor aktual yang didapatkan adalah 86,36\% dan ini termasuk kedalam kategori sangat valid. Kepraktisan modul elektronik fisika teknikdapat dilihat dari hasil angket small group dan hasil angket field test denganrata-rata persentase skor angket untuk tahapuji cobas mall group dan uji lapangan (field test) adalah 80,25\%, termasuk dalam kategori praktis. Sedangkan untuk efek potensial dilihat dari hasil pre test dan post test. Ratarata nilai mahasiswa pada saat pre test yaitu 61,36 dan pada saat post test nilai rata-rata yang diperoleh yaitu 89,09. Berdasarkan klasifikasi nilai gain maka efektifitas dari pengembangan modul elektronik fisika teknikini termasuk dalam kategori "tinggi" dengan nilai gain 0,71. Dari hasil tersebut dapat dikatakan bahwa modul elektronik berbasis POEI tergolong efektif.
\end{abstract}

Kata kunci: modul elektronik, POEI, fisika teknik

\begin{abstract}
This research purpose to produce Learning Media in the form of E-Modules Based on POEI (Prediction, Observation, Experiments, Interpretations) in Engineering Physics that is valid, practical and effective.The development procedure consists of four stages: Define (Defining), Design (Planning), Develop (Development) and Desseminate (Dissemination). The validity of electronic engineering physics modules is seen from the results of material and media validation. The actual score obtained from material validation is $80 \%$ and this is in the valid category. Then for media validation the actual score obtained is $86.36 \%$ and this is included in the very valid category. The practicality of electronic physics engineering modules can be seen from the results of the small group questionnaire and the results of the field test questionnaire with the average percentage of questionnaire scores for the small group trial stage and field test (field test) is $80.25 \%$, included in the practical category. potential effects seen from the results of the pre test and post test. The average score of students at the pre test was 61.36 and at the post test the average score obtained was 89.09. Based on the classification of gain values, the effectiveness of the development of electronic engineering electronic modules is included in the "high" category with a gain of 0.71. From these results it can be said that poei-based electronic modules are classified as effective.
\end{abstract}

Keywords: electronic module, POEI, engineering physics 


\section{PENDAHULUAN}

Perkembangan teknologi semakin pesat dan tidak bisa dibendung. perkembangan teknologi tersebut berpengaruh pada dunia pendidikan melalui kegiatan pembelajaran berbasis Teknologi Informasi dan Komunikasi (TIK) yang memungkinkan tenaga pendidik untuk semakin berinovasi dalam membuat Media Pembelajaran yang lebih baik dan mendorong mahasiswa untuk menggunakan TIK dalam memudahkan belajar (Rusman \& Riana, 2011). Nurchali (2010) juga menyatakan bahwa pemanfaatan komputer dalam pembelajaran dapat memberikan pengalaman belajar yang banyak dan variatif, meningkatkan motivasi belajar serta mengembangkan keterampilan TIK (Teknologi Informasi dan Komputer) mahasiswa. TIK adalah perangkat teknologi yang memfasilitasi penggunanya dengan berbagai kemudahan dalam mengakses informasi yang dibutuhkan, baik informasi yang disajikan dalam bentuk audio, tulisan, visual, maupun dalam bentuk simbol atau lambang-lambang informasi (Prawiradilaga, 2016).

Pengembangan Media Pembelajaran berbentuk modul diterapkan dengan menggunakan komputer menjadi salah satu pemanfaatan TIK. Menurut Sanjaya (2012) media pembelajaran meliputi perangkat keras (hardware) dan perangkat lunak (software). Hardware adalah alat-alat yang dapat mengantar pesan seperti Over Head Proyektor, radio, televisi dan sebagainya. Sedangkan software adalah isi program yang mengandung pesan seperti informasi yang terdapat pada transparansi atau buku dahanbahan cetakan lainnya, cerita yang terkandung di dalam film atau materi yang disuguhkan dalam bentuk bagan, grafik, diagram, dan lain sebagainya. Menurut Arsyad (2011) kata media berasal dari bahasa latin medius yang secara harfiah berarti tengah, perantara atau pengantar. Dalam bahasa Arab media adalah perantara atau pengantar pesan dari pengirim kepada penerima pesan. Dari pengertian tentang media di atas, media dapat diartikan sebagai semua sarana dan alat yang dapat digunakan dan memudahkan seseorang untuk melakukan pembelajaran baik berupa informasi, peralatan dan sumber belajar. Dengan penggunaan media diharapkan proses pembelajaran akan lebih menarik dan berdampak positif bagi siswa dalam menemukan konsep pengetahuan (kognitif) yang dipelajari.

Meskipun perkembangan layanan komunikasi dengan berbasis komputer berkembang pesat sejalan dengan perkembangan teknologi dan komunikasi, namun pemanfaatan dalam dunia pendidikan masih terbatas (Amir, 2013). Oleh karena itu, peneliti mencari alternatif pemecahan masalah untuk membantu mahasiswa belajar, tidak dipungkiri tenaga pendidik dituntut untuk mengembangkan Media Pembelajaran yang mumpuni agar proses kegiatan belajar sesuai yang dibutuhkan peserta didiknya. Media Pembelajaran yang dikembangkan oleh tenaga pendidik tersebut dapat memenuhi kebutuhan peserta didiknya. Selain itu peneliti berusaha menggabungkan pengembangan media pembelajaran dan pemanfaatan teknologi komputer ini.

Modul bisa dikatakan suatu bentuk bahan ajar yang memungkinkan digunakan dalam proses pembelajaran (Prawiradilaga, 2008). 
Dalam ruang lingkup pembelajaran, modul memiliki arti sebagai unit lengkap yang berdiri sendiri yang tersusun dari rangkaian kegiatan belajar yang tersusun untuk membantu peserta didik agar bisa mencapai tujuan pembelajaran(Sanjaya, 2008). E-Modul dapat dipandang sebagai media atau bahan ajar, tetapi dalam penelitian ini E-Modul dilihat sebagai media yang digunakan guru untuk meyampaikan materi. E-Modul atau modul elektronik ini menembus batasan ruang dan waktu, karena bisa dibuka dimanapun dan kapanpun (Suarsana \& Mahayukti, 2013). Modul elektronik yang memanfaatkan komputer ini bisa menyampaikan informasi dan tahapan selanjutnya disampaikan bukan dengan media $e$-modul yang memanfaatkan teknologi komputer.

Di sisi lain, metode pembelajaran POEI difokuskan pada mahasiswa dalam menemukan apa yang diprediksi, observasi, eksperimen dan Interpretasi (Winarko, 2013). Artinya bahwa mahasiswa dituntut kemampuannya dalam menerapkan atau menggunakan apa yang telah diketahui dalam situasi yang baru atau dapat memberikan kesimpulan terhadap apa yang diprediksi, diamati dan dieksperimenkan sehingga teori dapat teruji. Melalui metode ini siswa akan diberdayakan agar mau dan mampu berbuat untuk memperkaya pengalaman belajarnya (learning to do) melalui peningkatan interaksi dengan lingkungan fisik dan sosialnya, sehingga mampu membangun pemahaman dan pengetahuannya terhadap dunia disekitarnya (learning to know). Dari hasil interaksi dengan lingkungannya siswa dapat membangun pengetahuan dan kepercayaan diri sekaligus membangun jati diri (learning tobe).

Dari permasalahan yang telah diuraikan, Penelitian ini bertujuan untuk menghasilkan media pembelajaran dalam bentuk E-Modul berbasis POEI (Prediksi, Observasi, Ekperimen, Interpretasi) Pada Mata Kuliah Fisika Teknikyang valid, praktis dan efektif. Berdasarkan penelitian sebelumnya terkait dengan e-modul yaitu pengembangan E-Modul Berbasis Model Pembelajaran Project Based Learning pada Mata Pelajaran Videografi untuk Siswa Kelas X Desain Komunikasi Visual di SMK Negeri 1 Sukasada dinyatakan berhasil diterapkan di mana siswa terlihat antusias dan lebih aktif selama proses pembelajaran berlangsung, belajar tuntas dan dapat meningkatkan kualitas pembelajaran (Priatna dkk, 2017). Penelitian e-modul lainnya juga menyatakan bahwa e-modul mendapatkan penilaian positif dikarenakan materi pembelajaran menjadi sangat mudah dipahami oleh siswa (Fausih, 2015).

\section{METODE PENELITIAN}

Penelitian ini merupakan penelitian dan pengembangan atau Research and Development (Sugiyono, 2015) dengan menggunakan model pengembangan Four D (Mulyatiningsih, 2011). Prosedur pengembangan terdiri dari empat tahap yaitu: Define (Pendefinisian), Design (Perencanaan), Develop (Pengembangan) dan Desseminate (Penyebarluasan). Dalam tahap Define (Pendefinisian) diilakukan kegiatan menganalisis kebutuhan pengembangan, syarat-syarat pengembangan produk yang sesuai dengan kebutuhan pengguna serta model penelitian dan pengembangan yang 
cocok digunakan untuk mengembangkan produk. Dalam konteks pengembangan bahan ajar tahap pendefinisian dilakukan dengan cara analisa kurikulum, analisa karakter peserta didik, analisa materi dan tujuan, tahap selanjuntya adalah design (Perancangan). Dalam tahap perancangan, peneliti sudah membuat produk awal (prototype). Sebelum rancangan (design) produk dilanjutkan ketahap berikutnya, maka rancangan produk (modul, buku ajar, dsb) tersebut perlu divalidasi. Validasi rancangan produk dilakukan oleh teman sejawat seperti dosen atau guru dari bidang/ studi keahlian yang sama. Berdasarkan hasil validasi teman sejawat tersebut, ada kemungkinan rancanmgan produk tersebut masih perlu diperbaiki sesuai dengan saran validator. Setelah tahap perancangan dilanjutkan dengan pengembangan (Develop), Tahap pengembangan dilakukan dengan cara menguji isi dan keterbacaan modul kepada pakar yang terlibat ada saat validasi rancangan dan peserta didik yang akan menggunakan modul. Hasil pengujian kemudian dipergunakan untuk revisi sehingga modul atau buku ajar tersebut benar-benar memenuhi kebutuhan pengguna. Dalam konteks pengembangan bahan ajar (buku atau modul), tahap pengembangan dilakukan dengan cara menguji isi dan keterbacaan modul atau buku ajar tersebut kepada pakar yang terlibat ada saat validasi rancangan dan peserta didik yang akan menggunakan modul atau buku tersebut. Hasil pengujian kemudian digunakan untuk revisi sehingga modul atau buku ajar tersebut benar-benar memenuhi kebutuhan pengguna. Tahap terakhir yaitu penyebarluasan (Disseminate),
Thiagarajan membagi tahap dissemination kedalam tiga tahap kegiatan yaitu: Validation testing, packaging. Diffusion and adoption. Pada tahap validation testing, produk yang sudah direvisi pada tahap pengembangan kemudian diimplementasikan pada sasaran yang sesungguhnya. Pada saat implementasi dilakukan pengukuran ketercapaian tujuan. Pengukuran ini dilakukan untuk mengetahui efektifitas produk yang dikembangkan.

Tujuan yang belum dapat tercapai perlu dijelaskan solusinya sehingga tidak akan terulang kesalahan yang sama setelah produk disebarluaskan. Kegiatan terakhir dari tahap pengembanganyaitu melakukan packaging (pengemasan), diffusion and adoption. Pada Tahap konteks pengembangan bahan ajar, tahap dissemination dilakukan dengan cara sosialisasi bahan ajar melalui pendistribusian dalam jumlah terbatas kepada dosen dan mahasiswa.

Tahap pendefinisian adalah tahapan awal dalam melakukan penelitian dengan model pengembangan FourD. Tahap pendefinisian ini dilakukan dengan kegiatan analisis kebutuhan pengembangan serta syaratsyarat pengembangan produk yang sesuai dengan kebutuhan yang cocok digunakan untuk mengembangkan produk. Tahap pendefinisian dilakukan dengan cara analisis kurikulum, analisis karakteristik peserta didik, analisis materi, serta merumuskan tujuan.

Analisis kurikulum dilakukan dengan menganalisis silabus, kompetensi dasar, dan indikator pada mata kuliah fisika teknik. Kesimpulan yang diambil dari hasil analisis tersebut yaitu diperlukannya bahan ajar mandiri yang dapat berinteraksi dengan 
peserta didik yaitu berupa modul elektronik.

Dalam pengembangan bahan ajar analisis karakteristik peserta didik perlu diketahui untuk menyusun bahan ajar yang sesuai dengan kemampuan dan ketertarikan mahasiswa. Analisis karakteristik peserta didik dilakukan setelah menganalisis kurikulum. Metode yang digunakan dalam menganalisis karakteristik peserta didik yaitu wawancara terstruktur pada mahasiswa yang telah mengikuti mata kuliah fisika teknik. Wawancara tersebut dilakukan pada saat pra observasi.

Analisis materi dilakukan dengan cara mengumpulkan semua informasi yang berkaitan dengan materi yang akan disajikan dan menyusun materi tersebut secara sistematis. Dalam pengembangan modul elektronik berbasis POEI ini materi disajikan berdasarkan silabus mata kuliah pengukuran fisika teknik. Adapun sub materi yang disajikan yaitu besaran dan satuan, vector, gerak lurus dan gerak melingkar, gaya, usaha dan energy dan tegangan dan regangan.

Setelah tahap pendefinisian dilakukan langkah selanjutnya yitu tahap perancangan (Design) modul elektronik berbasis POEI. Program yang digunakan untuk membuat modul elektronik ini yaitu menggunakan Flip Book Maker. Pada tahap perancangan ini, peneliti sudah membuat produk rancangan awal modul elektronik berbasis POEI. Modul elektronik ini membahas satu indikator yaitu mengenai besaran dan satuan, vector, gerak lurus dan gerak melingkar, gaya, usaha dan energy dan tegangan dan regangan.

Setelah tahap perancangan (Design) selesai, langkah selanjutnya adalah tahap pengembangan modul elektronik. Dalam tahapan pengembangan ini dibagi kedalam dua tahap yaitu expert apparaisal merupakan teknik memvalidasi atau menilai kelayakan produk seperti validasi ahli materi dan media. Yang kedua yaitu Development testing merupakan kegiatan uji coba rancangan produk pada sasaran subjek yang sesungguhnya seperti uji coba pertama, uji coba kedua dan uji coba ketiga (uji lapangan).

\section{HASIL DAN PEMBAHASAN}

\subsection{Hasil Penelitian}

Pada uji coba pertama dilakukan validasi oleh ahli yang digunakan untuk mengukur kevalidan baik dari segi materi maupun media. Validasi yang pertama dilakukan yaitu validasi materi modul elektronik fisika teknik yang didapatkan hasil validasi materi sebesar $80 \%$, dapat disimpulkan bahwa modul elektronik berbasis $P O E I$ valid untuk digunakan sebagai bahan ajar fisika teknikserta sebagai bahan belajar mandiri mahasiswa. Pada saat validasi, validator menyatakan bahwa modul elektronik layak di uji coba dengan revisi. Adapun revisi dari ahli materi yaitu deskripsi materi yang dibuat harus jelas dan diberikan contoh setiap pokok bahasan. Setelah melakukan validasi materi langkah selanjutnya adalah validasi media modul elektronik. Berdasarkan hasil persentase kevalidan, disimpulkan bahwa modul elektronik berbasis $P O E I$ sangat valid untuk digunakan sebagai bahan ajar fisika teknik serta sebagai bahan belajar mandiri mahasiswa dengan presentase kevalidan 90\%. Validasi media dilakukan untuk mengetahui kelayakan media yang telah dibuat. Pada saat validasi, validator menyatakan bahwa modul elektronik layak di uji coba dengan revisi. 
Adapun revisi dari ahli media yaitu perbaiki desain cover, kontras wana, pemilihan huruf.

Uji coba kedua ini di uji cobakan pada enam mahasiswa palembang. Skor angket pada uji coba kedua adalah $80.9 \%$, persentase ini berada dalam renang $61 \%-80 \%$ yang masuk dalam kategori praktis, sehingga modul elektronik berbasis POEI mata kuliah fisika teknik ini layak diujicobakan pada uji coba ketiga (uji lapangan). Pada uji coba kedua salah satu mahasiswa berkomentar bahwa soal latihan ada yang tidak sesuai dengan contoh.

Uji coba ketiga dilakukan kepada mahasiswa pendidikan teknik mesin angkatan 2016 Indralaya sebanyak dua puluh orang dengan catatan mahasiswa yang belum melakukan uji coba pertama. Uji coba ketiga ini dilakukan untuk mengukur tingkat keefektifan modul elektronik berbasis POEI. Berdasarkan hasil pre test dan post test yang dihitung dengan standar gain diketahui sebanyak 13 mahasiswa termasuk kedalam ketegori "tinggi" sedangkan 9 mahasiswa termasuk kedalam kategori "sedang" dan tidak ada mahasiswa yang termasuk kedalam kategori "rendah". Rata-rata nilai mahasiswa pada saat pre test yaitu 61,36 dan pada saat post test nilai rata-rata yang diperoleh yaitu 89,09 maka dari hasil data yang diambil dari pre test dan post test didapatkan menggunakan rumus $\mathrm{N}$-gain untuk melihat efek potensial dijumlahkan dalam rata-rata.

$$
\begin{aligned}
N \text {-gain }(g)= & \frac{S \text { post }-S \text { pre }}{S \text { maks }-S \text { pre }} \\
N \text {-gain }(g)= & \frac{89,09-61,36}{100-61,36}
\end{aligned}
$$

$N$-gain $(g)=\frac{27,73}{38,64}$

$$
N \text {-gain }(\boldsymbol{g})=0,71
$$

Berdasarkan klasifikasi nilai gain maka efektifitas dari pengembangan modul elektronik fisika teknik ini termasuk dalam kategori "tinggi" dengan nilai gain 0,71. Jika data analisis nilai pre test dan post test disajikan dalam diagram maka dapat disajikan sebagai berikut.

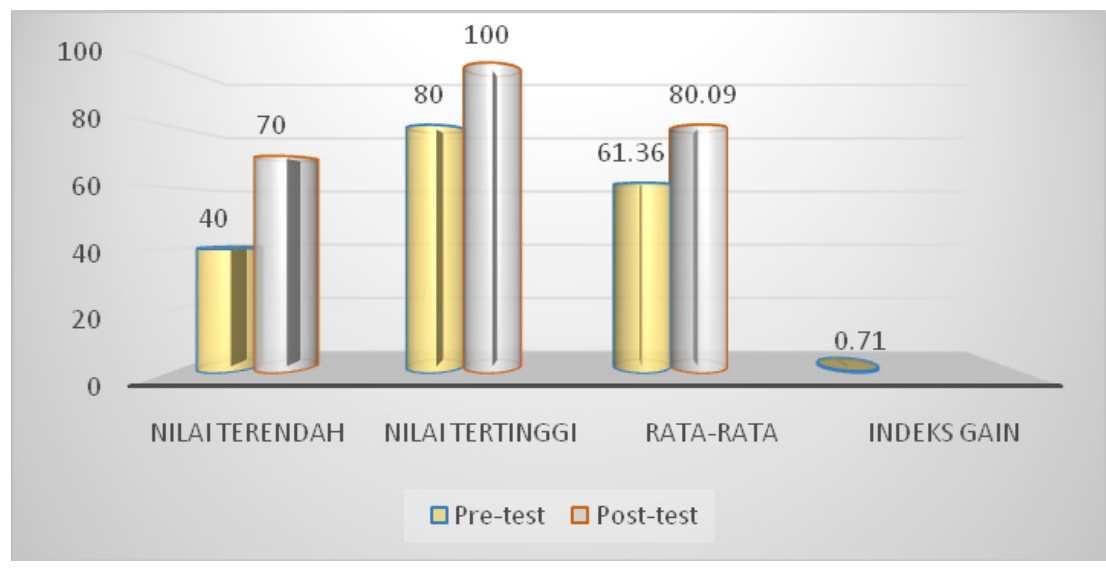

Gambar 1 Diagram Analisis Nilai Pre Test dan Post Test

Setelah soal post test selesai dikerjakan, peneliti meminta mahasiswa untuk mengisi angket yang peneliti sediakan untuk mengukur kepraktisan modul pada tahap uji lapangan (field test). Jumlah total skor yang diperoleh yaitu 1752,6 sedangkan jumlah skor maksimum 2200. Adapun perhitungan kepraktisan angket pada tahap field test adalah sebagai berikut: 


$$
\text { Persentase Skor Kepraktisan }(\%)=\frac{1752,6}{2200} \times 100 \%=79,6 \%
$$

Persentase skor kepraktisan modul elektronik pada tahap field test adalah 79,6\%. Persentase ini berada dalam rentang $61 \%-$ $80 \%$ yang termasuk dalam kategori praktis.

\subsection{Pembahasan}

E-modul merupakan alat atau sarana pembelajaran yang berisi materi, metode, batasan-batasan dan Author surnames go here 3 cara mengevaluasi yang dirancang secara sistematis dan menarik untuk mencapai kompetensi yang diharapkan sesuai dengan tingkat kompleksitasnya secara elektronik (Diantari dkk, 2018). Winarko (2013) menyatakan bahwa peran modul elektronik ini adalah dapat memasukkan teknologi sebagai media belajar sehingga secara tidak langsung siswa telah berinteraksi dengan teknologi artinya dapat menggunakan komputer dalam pembelajaran. Di sisi lain, media elektronik sendiri dapat menjadikan proses pembelajaran lebih menarik, interaktif, dapat dilakukan kapan dan dimana saja serta dapat meningkatkan kualitas pembelajaran (Sugianto, 2013).

Pengembangan e-modul berbasis POEI (Prediksi, Observasi, Ekperimen, Interpretasi) pada mata kuliah fisika teknik dilakukan dengan tiga tahap uji coba yang meliputi tahap validasi, kepraktisan dan keefektifan. Uji coba pertama dilakukan dengan menggunakan lembar wawancara tertulis berupa komentar, kritik serta saran pada modul elektronik ini. Dengan hasil wawancara, modul elektornik ini bisa digunakan dan pembelajaan lebih efektif. Peneliti memperlihatkan dan ketiga mahasiswa menggunakan modul elektronik berbasis $P O E I$ mata kuliah fisika teknik kepada ketiga mahasiswa tersebut setelah itu meminta mereka menuliskan komentar, kritik dan saran pada lembar yang telah disediakan. Komentarkomentar tersebut nantinya akan dijadikan bahan pertimbangan untuk meperbaiki kembali modul elektronik. Hasil dari revisi komentar dan saran expert review (validasi ahli) dan masukan pada tahap uji coba pertama berupa prototipe II diuji coba pada uji coba kedua (Kelompok kecil).

Dalam uji coba kedua ini peneliti memperlihatkan modul elektronik kepada mahasiswa dan meminta mereka mengoperasikannya. Setelah memperlihatkan modul elektronik mata kuliah fisika teknik berbasis POEI, peneliti meminta mahasiswa untuk mengisi angket dengan menceklis pilihan yang tersedia untuk mengukur kepraktisan modul elektronik berbasis berbasis POEI, mata kuliah fisika teknik. Komentar dan saran dilembar belakang angket menjadi pertimbangan tindakan penelitian merevisi modul elektronik berbasis POEI mata kuliah fisika teknik.

Sebelum melakukan uji coba ketiga, peneliti menyiapkan soal pre test dan soal post test. Peneliti memberikan soal pre test berupa soal pilihan gandayang terdiri dari 20 soal Soal pretest inibertujuan untuk mengetahui kemampuan awal mahasiswa. Setelah memberikan soal pre test, mahasiswa diberi kesempatan untuk membaca dan menggunakan modul elektronik fisika teknik. Mahasiswa diminta untuk memahami materi yang ada pada modul elektronik tersebut. Setelah mahasiswa menggunakan modul elektronik Fisika, Teknik peneliti memberikan 
soal post test berupa pilihan ganda sebanyak 20 soal yang digunakan untuk mengetahui efek potensial kemampuan akhir mahasiswa setelah menggunakan modul elektronik.

\section{SIMPULAN}

Berdasarkan hasil penelitian dan analisis data yang telah diuraikan maka disimpulkan modul elektronik fisika teknik tergolong valid, hal ini dilihat dari hasil validasi materi adalah $80 \%$ dan masuk kategori valid dan untuk validasi media skor aktual yang didapatkan adalah $86,36 \%$ termasuk kedalam kategori sangat valid. Modul elektronik fisika teknik tergolong praktis. Hal ini dilihat dari rata-rata persentase skor angket untuk taha puji coba small group dan uji lapangan (field test) adalah 80,25\%. Modul elektronik fisika teknik tergolong efektif. Hal ini dilihat dari klasifikasi nilai gain yang termasuk dalam kategori "tinggi" dengan nilai gain 0,71 .

\section{DAFTAR RUJUKAN}

Amir, R.(2013). Strategi \& Desain Pengembangan Sisitem Pembelajaran. Jakarta: Prestasi Pustaka.

Arsyad, A.(2011). Media Pembelajaran. Jakarta : PT. Raja Grafindo Persada.

Diantari, L. P. E., Damayanthi, L. P. E., Sugihartini, N \& Wirawan, M. A. (2018). Pengembangan E-Modul Berbasis Mastery Learning Untuk Mata Pelajaran KKPI Kelas XI. Jurnal Nasional Pendidikan Teknik Informatika (JANAPATI), 7 (1), 33-48.

Fausih, M., \& Danang, T. (2015). Pengembangan Media E-modul Mata Pelajaran Produktif Pokok Bahasan Instalasi Jaringan LAN (Local Area Network) untuk Siswa Kelas XI Jurusan Teknik Komputer Jaringan di SMK Negeri 1 Labang Bangkalan Madura. Diakses dari http://jurnalmahasiswa.unesa.ac.id/index. php/jmtp/article/view/10375/10123 pada 23 November 2018.

Mulyatiningsih, E. (2011). Evaluasi Proses Suatu Program. Bumi Aksara. Jakarta.

Nurchali. (2010). Pengaruh Media Pembelajaran Berbasis Teknologi Informasi dalam Pembelajaran Kimia Terhadap Peningkatan Hasil Belajar Mahasiswa. Jurnal Pendidikan dan Kebudayaan, 16, 648 - 658.

Nurmayanti, F., Bakri, F \& Budi, E. (2015). Pengembangan Modul Elektronik Fisika dengan Strategi PDEODE pada Pokok Bahasan Teori Kinetik Gas untuk Siswa Kelas XI SMA. Prosiding Simposium Nasional Inovasi dan Pembelajaran Sains 2015 (SNIPS 2015) 8 dan 9 Juni 2015, Bandung, Indonesia.

Prawiradilaga, D. S. (2008). PrinsipDesain Pembelajaran. Jakarta: Kencana Prenada Media Group.

Prawiradilaga, D. S. (2016). Mozaik Teknologi Pendidikan: E-Learning. Jakarta: Kencana Prenada Media Group.

Priatna, K., Putrama, M \& Divayana, D. G. H. (2017). Pengembangan E-Modul Berbasis Model Pembelajaran Project Based Learning Pada Mata Pelajaran Videografi untuk Siswa Kelas X Desain Komunikasi Visual di SMK Negeri 1 Sukasada. Jurnal Nasional Pendidikan Teknik Informatika (JANAPATI), 6 (1), 70-76.

Rusman, K. D \& Riyana C. (2011).Pembelajaran Berbasis Teknologi Informasi dan Komunikasi (Mengembangkan Profesionalitas Guru). Jakarta : PT Rajagrafindo Persada.

Sanjaya, W.(2008). Strategi Pembelajaran Berorientasi Standar Proses Pendidikan. Jakarta: Kencana Prenada Media Group.

Sanjaya, W. (2012). Media Komunikasi Pembelajaran. Jakarta: Kencana.

Suarsana, I. M \& Mahayukti, G. A. (2013). Pengembangan E-Modul Berorientasi Pemecahan Masalah untuk Meningkatkan Ketrampilan Berpikir Kritis Mahasiswa. Jurnal Nasional Pendidikan Teknik Informatika (JANAPATI), 2 (3), 193-200.

Sugianto, Dony dkk. (2013). Modul Virtual: Multimedia FlipBook Dasar Teknologi Digital. Jurnal INVOTEC, 9 (2), 110-116

Sugiyono. (2015). Metode Penelitian Kuantitatif, Kualitatif, dan R \& D. Bandung: Alfabeta

Winarko, A. S., Sunarno, S \& Masykuri, M. (2013). Pengembangan Modul Elektronik Berbasis POEI (Prediksi, Observasi, Eksperimen, Interpretasi) Pada Materi Sistem Indera Kelas Xi SMA Negeri 3 Ponorogo. BIOEDUKASI, 6 (2), 58-75. 